\title{
Cold mashing - Analysis and optimization of extraction processes at low temperatures in the brewing process
}

\author{
Niklas Schöttke ${ }^{1,2}$, and Frank Rögener ${ }^{2, *}$ \\ ${ }^{1}$ Pfeifer \& Langen GmbH \& Co. KG, Aachener Straße 1042a, D-50858 Köln, Germany \\ ${ }^{2}$ Technische Hochschule Köln, Institut für Anlagen und Verfahrenstechnik, Betzdorfer Str. 2, 50679 Köln, Germany
}

\begin{abstract}
According to indications, already 5,000 years ago beer was brewed without heating the mash, i.e. in the cold mash process. Applying this old method, the question arises to what extent this traditional knowledge can be integrated into today's brewing processes and to produce new beer styles at reduced energy consumption. Since cold mashing is hardly explored, this work is dedicated to in-depth analysis from a process and brewing point of view. Based on theoretical considerations of the mashing process, cold mashing formulations were estimated and analysed. Parameters for the experimental investigations were temperature, particle size of grinded grains, mixing ratio between malt and water, mashing time and the application of various multistage extraction processes. Additionally, at the optimum cold mashing conditions, a brew of about $10 \mathrm{~L}$ was produced, which confirmed the positive effects of the application of cold mash: Fermentation time is significantly reduced due to the composition of the cold-extracted malt components.
\end{abstract}

\section{Introduction}

The commercial beer market is currently dominated by two production concepts, which to some extend compete with each other: large-scale industrial breweries, often linked by corporate structures, are juxtaposed with small privately run breweries. These so-called microbreweries stand for craft beer and produce in small quantities individual and - sometimes very unusual - beer styles [1]. On the other hand, larger breweries often rely on beer styles, which appeal to the widest possible range of consumers [2]. Due to the highly competitive situation in the German beer market [3], the demand for new products ensures that brewers experiment with still unknown or forgotten beer styles [1]. In accordance with current trends, possible health benefits of beer as a source of vitamins, minerals or antioxidants were investigated [4-6]. Furthermore, energy and raw material savings in the production process are a strong driving force for all brewers to improve processes. However, the Reinheitsgebot restricts openness to experiments in German breweries.

Against this background, archaeological discoveries associated with the production of the first beers are gaining in importance. There is evidence that 5,000 years ago beers were produced without heating the mash, i.e. in the cold mash process [7, 8, 9]. However, if this brewing method has been used, very low alcohol concentrations of not more than 2 vol.- $\%$ must be assumed [7].

Mashing involves material conversion (water-soluble sugar is enzymatically produced out of starch) and material transfer (the generated sugar is dissolved in water). Mashing is the first biochemical process step of brewing and completes the enzymatic degradation, which is initiated during malting. In this process, enzymes are synthesized. These are essential for the degradation of large molecules during the subsequent mashing [10].

According to Koljonen et al., the applied temperature profile during mashing determines the chemical composition of the malt wort [11].

The balance between carbohydrates and proteins is important for beer brewing using barley malt, as high protein content reduces primarily the amount of available carbohydrates [10].

Steiner et al. mention that proteins in the form of enzymes - also in combination with other substances such as polyphenols - affect the whole brewing process. Enzymes degrade starch, b-glucans, and proteins [10].

Temperature levels, as well as variations of the retention time, do not only affect the duration of mashing and the content of dissolved fermentable sugars, but also the degree of fermentation, flavour and foam of the beer [12].

The quality of beer depends on several measurable parameters, which are based on the raw material and the brewing conditions. These involve e.g. colour, clarity, foam appearance, and flavour [13]. But to a large extend, the expression "quality" is defined by the individual consumers $[14,15]$.

This study was performed to evaluate the effect of cold mashing and multiple staged mashing procedures on wort composition and the effect cold mashing would

\footnotetext{
* Corresponding author: frank.roegener@,th-koeln.de
} 
have on barley malt beer. Cold mashing is not common and is only used by a few experimental microbreweries for the production of a few beer specialties. Malt and water are mixed without additional heating. Afterwards, wort (extract) and brewers grain are separated from each other. Resting or warming of partial mashes is eliminated. After cold mashing and lautering, the resulting wort is boiled to kill germs like in the conventional process [16].

From the results obtained, trends and correlations are derived, which are intended to explain on the one hand the reactions and on the other hand to design cold-mash processes. Finally, economic conclusions are drawn from the technical parameters obtained

\section{Materials and methods}

\subsection{Raw materials}

The investigations of cold mashing were carried out with tap water supplied by Rheinenergie Köln, Germany.

The malt employed for cold mashing was basic malt of the type Viennese malt (manufacturer Weyermann), which is made of summer barley. The kiln drying process leads to a coloration of the malt between EBC 5.5 and EBC 6.5. The used malt consists of 66 wt.- $\%$ carbohydrates, which contain 4 grams of sugar per 100 grams of malt.

Two malt grists from Weyermann were used as reference samples: Malt type 1 was Viennese malt (EBC: $5,5-6,5)$, type 2 was Pilsen malt (EBC: 2,5 - 3,5). Both reference samples are offered as standard grain for brewers without further specification.

For the detection of complete sacharification of starch, an iodine test with iodine N 50 solution was employed.

\subsection{Milling}

For milling, a cast iron malt mill with a capacity up to 30 $\mathrm{kg}$ /hour from Victoria was used. The grinding gap can be adjusted infinitely with the help of different washers. Accordingly, the denotations refer to employed washer heigt, e.g. M 1,75 means a washer height of $1.75 \mathrm{~mm}$.

\subsection{Mashing}

Mashing was done with a French press type Caffettiera French Press with a volume of $1 \mathrm{~L}$ from Bodum. The height was $175 \mathrm{~mm}$, the inner diameter was $90 \mathrm{~mm}$. Solid and liquid phase were separated by the filter element of the French Press with a mesh size of $0.5 \mathrm{~mm}$.

\subsection{Test brew based on cold mashing}

A mashing kettle type DRE 3000 P W00 from Saier with a volume of $30 \mathrm{~L}$ was used for the production of cold mashed beer. For the subsequent lautering a bottom plate type Läuterboden $357 \mathrm{~mm}$ from Mattmill was used.

\subsection{Physical and chemical analyses}

\subsubsection{Weighing}

For mass estimations, a precision scale type $3000 \times 0.1 \mathrm{~g}$ digital balance from Tykee was used. The accuracy is $+/-$ $0.1 \mathrm{~g}$.

\subsubsection{Temperature}

For temperature estimations, a Pt1000 thermometer type GTH 175/PT from Giesinger was used. It has a measurement range from $-199.9{ }^{\circ} \mathrm{C}$ to $+199.9{ }^{\circ} \mathrm{C}$. The accuracy is $0.1^{\circ} \mathrm{C}$.

\subsubsection{Sugar content}

For the estimation of the Brix units, a refraktometer type RHB-32SG from RZ was used. It has a measurement range from 0 to 32 . The accuracy is $0,2 \%$.

\section{$2.5 .4 \mathrm{pH}$}

For the estimation of the $\mathrm{pH}$ an electode type SE $102 \mathrm{~N}$ from Knick was used. It has a measurement range from $\mathrm{pH} \mathrm{0-14}$ at an accuracy of $+/-0,01$. The temperature range is $-5-100{ }^{\circ} \mathrm{C}$.

\subsubsection{Light microscopy}

The analysis took place in the lab of WESTO Hydraulik GmbH, Pulheim. A light microscope Typ: MM-KKE-M$\mathrm{C}-\mathrm{U}$ from Hydac was used, which allows enlargements 2,5:1, 4:1, 10:1, and 20:1.

\subsubsection{HPLC}

High pressure liquid chromatography (HPLC) is a chromatographic technique employed for the identification and quantification of the individual organic components of a solution [10]. The estimation of the extract composition by HPLC took place at Pfeifer \& Langen Innovations Center in Elsdorf, Germany.

\subsubsection{Particle size}

For the estimation of the particle size of the milled grains, a sieving machine type Vibro from Retsch was used. The sieve tower was equipped in accordance with the current standard DIN 4188 (MEBAK).

\section{Results}

Based on the theoretical background [16, 17], cold mashes were prepared and analyzed. For this purpose, malt was used in various dry milled grain fractions. Amongst others, milling conditions are supposed to have a strong impact on wort quality [18]. Varied parameters in cold mashing were temperature, grain size of the malt, mixing ratio of malt and water, mash time and various 
multi-stage process variations. Investigated parameters were the concentration of dissolved extracts after mashing, the compositions of the extractives, the $\mathrm{pH}$ of the mash and the qualitative detection of starch.

Malt load was varied between 0.15 and $0.025 \mathrm{~g}_{\text {Malt }} /$ $\mathrm{g}_{\text {Water, }}$ as these values are typical of conventional brewing processes [19].

Table 1 shows the performed investigations.

Table 1. Investigations.

\begin{tabular}{|c|c|c|c|}
\hline $\begin{array}{c}\text { Investigated } \\
\text { material }\end{array}$ & Parameter & Aim & $\begin{array}{l}\text { Analysis } \\
\text { methods }\end{array}$ \\
\hline \multirow[t]{3}{*}{ Malt grind } & Milling gap & $\begin{array}{l}\text { Condition } \\
\text { of husks }\end{array}$ & $\begin{array}{c}\text { Optical } \\
\text { evaluation }\end{array}$ \\
\hline & & $\begin{array}{l}\text { Particle } \\
\text { size } \\
\text { distribu- } \\
\text { tion } \\
\end{array}$ & $\begin{array}{l}\text { Sieving } \\
\text { machine }\end{array}$ \\
\hline & & $\begin{array}{c}\text { Form } \\
\text { factor } \\
\text { estimation }\end{array}$ & $\begin{array}{c}\text { Optical } \\
\text { evaluation } \\
\text { (partially light } \\
\text { microscopy) }\end{array}$ \\
\hline \multirow[t]{4}{*}{$\begin{array}{c}\text { Wort } \\
\text { (extract) }\end{array}$} & mixing ratio & $\begin{array}{l}\text { Extract } \\
\text { concentra- } \\
\text { tion }\end{array}$ & $\begin{array}{l}\text { Refractometer / } \\
\text { stop watch }\end{array}$ \\
\hline & $\begin{array}{l}\text { Tempera- } \\
\text { ture }\end{array}$ & $\begin{array}{l}\text { Extract } \\
\text { concentra- } \\
\text { tion }\end{array}$ & $\begin{array}{c}\text { Refractometer / } \\
\text { thermometer }\end{array}$ \\
\hline & $\begin{array}{l}\text { Residence } \\
\text { time }\end{array}$ & $\begin{array}{c}\text { Extract } \\
\text { composi- } \\
\text { tion and } \\
\text { pH }\end{array}$ & $\begin{array}{l}\text { HPLC and } \mathrm{pH} \\
\text { electrode }\end{array}$ \\
\hline & $\begin{array}{c}\text { Phases of } \\
\text { wort }\end{array}$ & $\begin{array}{l}\text { Control of } \\
\text { saccharif- } \\
\text { ication }\end{array}$ & Proof of starch \\
\hline $\begin{array}{l}\text { Self brewed } \\
\text { beer }\end{array}$ & & $\begin{array}{l}\text { Influence } \\
\text { of cold } \\
\text { mashing } \\
\text { on beer } \\
\text { quality }\end{array}$ & $\begin{array}{c}\text { Selected } \\
\text { brewing } \\
\text { parameters }\end{array}$ \\
\hline
\end{tabular}

\subsection{Particle size analysis}

The particle size of several self-milled grains as well as two commercial grains was estimated. Type 1 stands for Viennese malt, type 2 stands for Pilsen malt, s. figure 1.

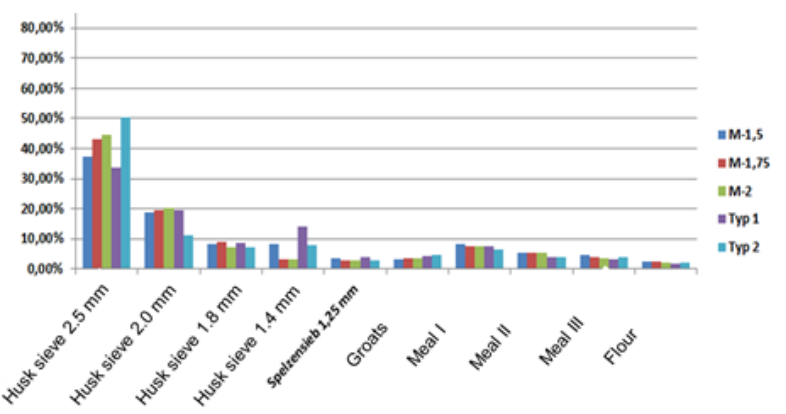

Fig. 1. Particle size distribution of the self -milled malt grist and the two commercial reference malt grists.

The analysis shows that the self-milled malt grists M1.5, M-1.75 and M-2 show particle size ranges comparable to the commercial grist types 1 und 2 .

\subsection{Influence of the malt load on the extract concentration in cold mashing}

The blue lines in Figure 2 mark all measurements in which 9 grams of self-milled malt were used as an extraction material. The green lines represent the use of 6 grams of malt, the red lines are based on a mixture of 3 grams of malt and 40 grams of water. 1.096 measurements were performed to estimate the curve of the extract concentation as a function of malt type and malt load $\left(\mathrm{g}_{\text {malt }} / \mathrm{g}_{\text {water }}\right)$.

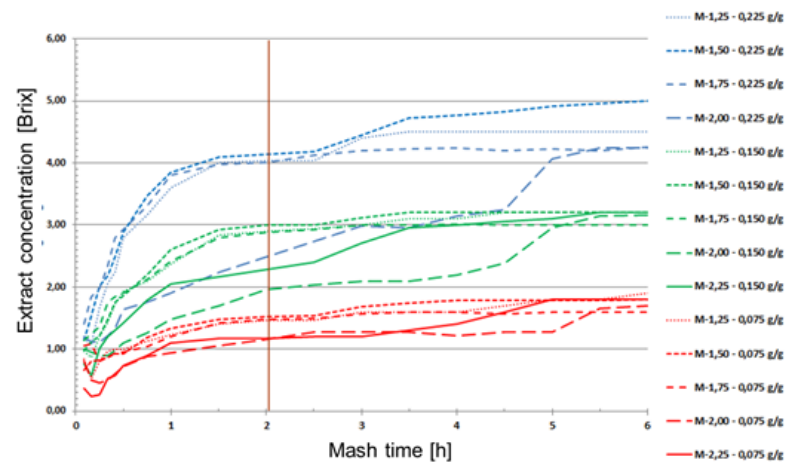

Fig. 2. Extract concentation as a function of malt type and malt load $\left(\mathrm{g}_{\text {malt }} / \mathrm{g}_{\mathrm{water}}\right)$ at room temperature.

At about 1.5-2 hours of mashing time, an optimum concerning the extract concentration can be seen. In figure 3 a comparison between 2 and 6 hours of mashing time is depicted.

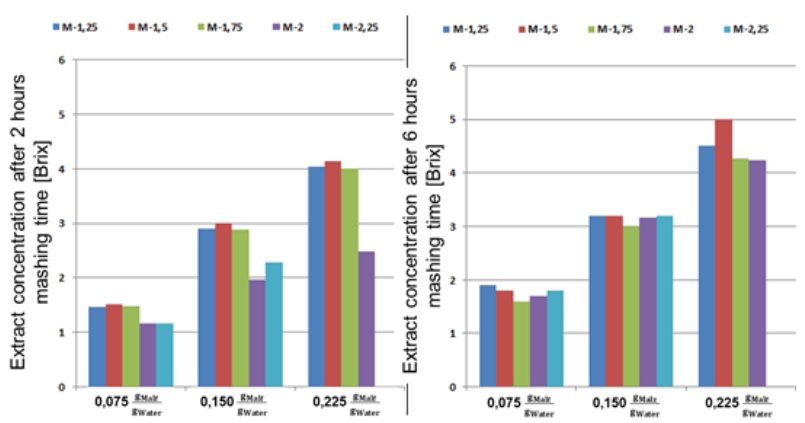

Fig. 3. Extract concentration after 2 and 6 hours mashing time at room temperature.

It can be seen, that when the mash time increases, the influence of grain size on extract concentration decreases.

M-1,75 was selected for further tests because M-1,5 and M-1,25 did not exhibit a sufficient lautering behavior.

\subsection{Influence of the temperature on the extract concentration in cold mashing}

During the test series described above, the temperature was in a range between 17.5 and $19.5^{\circ} \mathrm{C}$. In the next stage of the study, it was examined to what extent temperature fluctuations in the range between 11 and 26 ${ }^{\circ} \mathrm{C}$ show a result-relevant influence on the achieved extract concentrations. Even if the temperature of the mash was never below $17{ }^{\circ} \mathrm{C}$ or above $20{ }^{\circ} \mathrm{C}$ during the 
performance, the temperature range for the examination was increased in order to evaluate to what extent the temperatures in these areas influence the mashing process. For the following trials, malt type M-1,75 was used. A malt load of $0.15 \mathrm{~g}_{\text {Malt }} / \mathrm{g}_{\text {Water }}$ - the mean value of the investigated malt load - was kept constant and the mashing temperature was varied. Figure 4 shows the results.

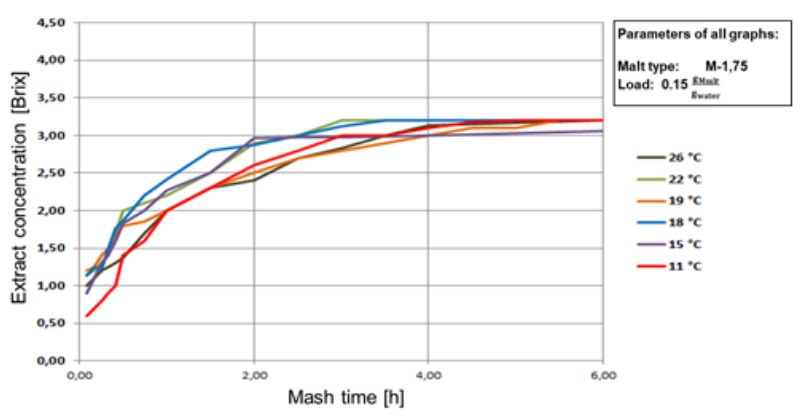

Fig. 4. Extract concentration as a function of cold mashing temperature.

No clear relation between cold mash temperature and extract concentration was detected.

\subsection{Extract composition in single-stage cold mashing}

Selected mash samples with a malt load of 0.15 $\mathrm{g}_{\text {Malt }} / \mathrm{g}_{\text {Water }}$ were examined chromatographically and the composition of the extract phase was determined. The composition of the worts studied is shown in Figure 5.

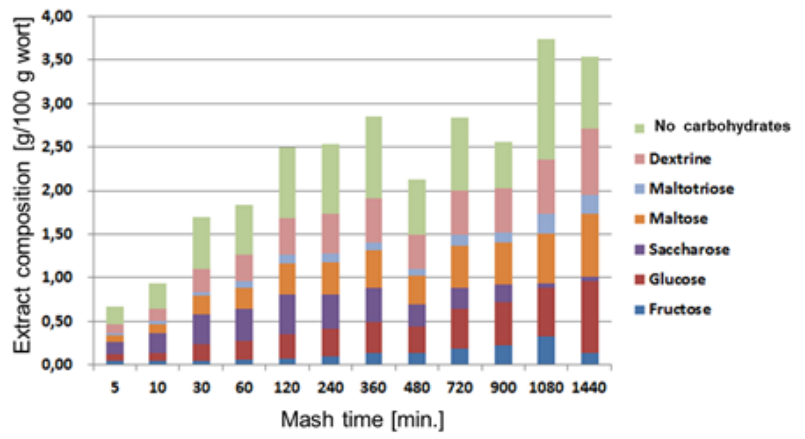

Fig. 5. Extract composition in single-stage cold mashing.

The composition of the respective worts shows increasing concentrations of maltose, glucose, and dextrins with increasing mash time.

\subsection{Extract composition in multistage cold mashing}

In addition to the single-stage procedures, investigations of the extraction behavior were carried out also in multistage crossflow and counterflow. Based on the singlestage studies described before, malt M-1,75 was used. As can be seen in figure 2, mash times larger than 2 hours do not contribute to a significant increase of the extract concentration. Accordingly, a mash time of two hours per stage was chosen. Figure 6 shows the results of the multistage investigations.

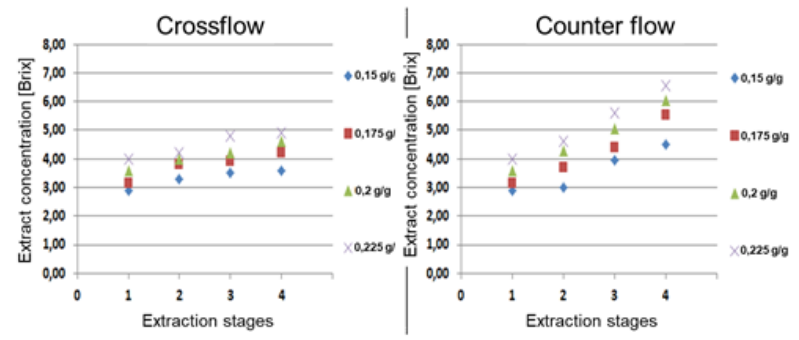

Fig. 6. Influence of multistage processes on extract concentrations.

As can be seen, the increase in the number of process steps has a greater influence in the counterflow than in the crossflow mode. A four-staged counterflow mashing process is the preferred solution to achieve high extract concentrations.

\subsection{Test brew based on cold mashing}

The generated cold-mashed beer meets the criteria of a light lager beer, s. table 2.

The taste turns out to be very light and the hops dominate the end of the sip.

Table 2. Characteristics of the generated cold-mashed beer.

\begin{tabular}{|c|c|}
\hline Parameter & Value \\
\hline Extract concentration before rest & 4.5 Brix \\
\hline Extract concentration after rest & 6.0 Brix \\
\hline Extract concentration calculated & 4.2 Brix \\
\hline $\begin{array}{c}\text { Energy savings compared to } \\
\text { conventional mashing }\end{array}$ & $32.8 \%$ \\
\hline $\begin{array}{c}\text { Relation of malt employed for cold } \\
\text { mashing compared to conventional } \\
\text { mashing }\end{array}$ & 2.48 \\
\hline Original gravity & $6.8{ }^{\circ} \mathrm{Plato}$ \\
\hline Brewhouse effciency & $28.8 \%$ \\
\hline Final gravity & $2.4 \mathrm{wt} . \mathrm{\%} \%$ \\
\hline Alcohol
\end{tabular}

\section{Discussion}

In the course of these studies, it was shown that small temperature fluctuations have no direct influence on the result of the cold mashing.

However, the selected particle size of the malt can be seen in the discord between mashing and lautering conditions. Accordingly, $\mathrm{M}-1,75$ is chosen as the preferred grain.

Due to the measured time histories, an ideal mash time per mashing stage of 2 hours is determined. This also in line with the lautering time on industrial scale. For batchwise beer production, a matching of the two process step times is favourable.

The optimum mixing ratio of water and malt needs to be defined according to the specifications chosen individually. Considering the relatively smaller amount of fermentable sugars in the generated wort and the composition of the extract with a high proportion of short-chained carbohydrates, a reduced fermentation 
time compared to conventional brewing processes is expected.

Multi-stage processes involving four reaction stages provide optimal results for a malt load of $0.175 \mathrm{~g}$ malt $/ \mathrm{g}$ water in both cross current and the countercurrent mode.

By applying iodine tests, it was shown that the extract dissolved in the wort does not contain any starch. However, the wort is clouded due to finely distributed solid components. These are highly starchy, but they could be saccharified by heating the wort. With regard to the relationship between material conversion and transfer of substances during mashing, it could be shown that the conversion of the substance is the decisive factor for increasing the extract concentration.

In a final calculation of the energy and malt demand required for cold mashing, a comparison was drawn with conventional mashing. It turned out that cold mashing can save up to $18.9 \%$ of the required energy, while the required malt mass increases by a minimum factor of 2.2 and a maximum factor of 5.2, see figure 7 .

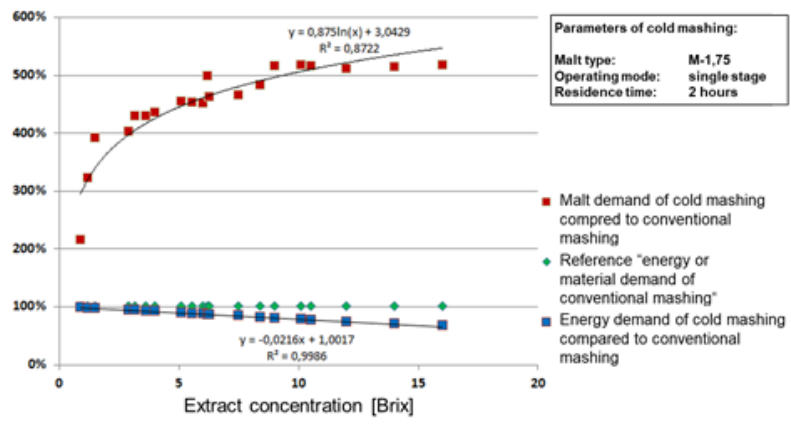

Fig. 7. Influence of multistage processes on extract concentrations.

\section{Conclusion}

From an economic point of view, the cold mashing process cannot be regarded as a substitute for conventional mashing, due to the greatly increased malt requirement with only small energy savings. However, cold-mashed beer can play a role in the trend of new, alternative beers. Thus, the material conversion and material transfer processes at temperatures in the range of $20{ }^{\circ} \mathrm{C}$ ensure that taste-slim and very light beers are produced. As a result, cold-mashed beer can be developed as a new type of beer that stands out from conventional beers in terms of taste and production.

In order to work as efficiently as possible in the production of cold-mashed beers, a multi-stage process management is recommanded. Thus, for the 4-stage countercurrent operation, with a loading of $0.175 \mathrm{~g}$ malt per $g$ of water, an increase in the extract concentration of more than $75 \%$ compared to the analogously performed single-stage method was determined. Also in cross current operation, the yield can be increased compared to the single-stage process.

The properties of the wort based on cold mashing provide a number of possibilities to change conventional brewing processes even after mashing. Cold-mashed worts reduce boiling and fermentation times and reduce the required hop mass, which increases the costeffectiveness of cold mashing. Furthermore, beers produced by cold mash are in the trend of alcoholreduced beers and thus calorie-reduced foods. This fact can be used as the basis for a successful marketing of the product.

The approaches shown in this work can be carried out without costly technical conversion of existing brewery equipment. Thus, cold mashing is an opportunity for each brewery to expand the product portfolio, create a new type of beer and enrich the beer market.

\section{References}

1. Deutscher Brauer-Bund e.V.: Zahl deutscher Brauereien wächst weiter. URL: https://www.brauer-

bund.de/index.php?id=930\&ageverify $=16 \&$ PHPSE $\mathrm{SSID}=021 \mathrm{~b} 103 \mathrm{a} 29 \mathrm{~d} 753301 \mathrm{~d} 0 \mathrm{da} 78 \mathrm{~b} 6 \mathrm{e} 145 \mathrm{~d} 3 \mathrm{a}$ (accessed: 26.03.2020)

2. H. Dornbusch: Brauwelt 37-38 (2019)

3. P. Henrich: Bierabsatz in Deutschland bis 2019. URL:

https:/de.statista.com/statistik/daten/studie/3406/um frage/bierabsatz-in-deutschland-seit-dem-jahr-1999/ (accessed: 26.03.2020)

4. L.C. Salanta et al., Processes 8 (2020)

5. S. Sohrabvandi, A.M. Mortazavian, K. Rezaei, Int. J. Food Prop. 15 (2012)

6. O.J.R. Neto et al., J. Funct. Foods 34 (2017)

7. P. Damerow, Cuneiform Digital Library Journal 2 (2012)

8. M. Zarnkow, A. Otto, B. Einwag, Interdisciplinary investigations into the brewing technology of the ancient Near East and the potential of the cold mashing process (Berghahn Books, New York, 2011)

9. M. Zarnkow et al., Cold mashing process - a technology possibly used in ancient times in the Orient. Brauwelt Int 5 (2006)

10. E. Steiner, M. Gastl, T. Becker, Eur Food Res Technol 232 (2011)

11. T. Koljonen, J. Hämäläinen, and K. Sjöholm, J. Food Eng. 26 (1995)

12. A. Juric et al., Inst. Brew. 121 (2015)

13. M. Moir, Brewers' Guardian 118 (1989)

14. M.A. Igyor et al., Process Biochemistry 36 (2001)

15. L. Salant et al., Bull. Univ. Agric. Sci. Vet. Med. 74 (2017)

16. L. Narziß: Abriss der Bierbrauerei. 7th, updated and extended edition (Wiley-VCH, Weinheim, 2005)

17. R. Schneid: Verfahrenstechnische Beeinflussungen des Maischens sowie dessen Auswirkungen auf den Brauprozess und die Bierqualität. Dissertation (TU Berlin, Berlin, 2019) 
18. F. Pereira de Moura, T.A. Rocha dos Santos Beverages 4 (2018)

19. W. Kunze: Technologie Brauer und Mälzer. 8th, updated edition (VLB, Berlin, 1998). 